\title{
Antioxidant and antimicrobial activities of ethyl acetate extract, fractions and compounds from stem bark of Albizia adianthifolia (Mimosoideae)
}

\author{
Jean de Dieu Tamokou ${ }^{1 *}$, Deke James Simo Mpetga ${ }^{2}$, Paul Keilah Lunga ${ }^{1,3}$, Mathieu Tene ${ }^{2}$, Pierre Tane ${ }^{2}$
} and Jules Roger Kuiate ${ }^{1}$

\begin{abstract}
Background: Albizia adianthifolia is used traditionally in Cameroon to treat several ailments, including infectious and associated diseases. This work was therefore designed to investigate the antioxidant and antimicrobial activities of ethyl acetate extract, fractions and compounds isolated from the stem bark of this plant.

Methods: The plant extract was prepared by maceration in ethyl acetate. Its fractionation was done by column chromatography and the structures of isolated compounds were elucidated using spectroscopic data in conjunction with literature data. The 1,1-diphenyl-2-picrylhydrazyl (DPPH) and trolox equivalent antioxidant capacity (TEAC) assays were used to detect the antioxidant activity. Broth micro-dilution method was used for antimicrobial test. Total phenol content was determined spectrophotometrically in the extracts by using Folin-Ciocalteu method.

Results: The fractionation of the extract afforded two known compounds: lupeol (1) and aurantiamide acetate (2) together with two mixtures of fatty acids: oleic acid and $n$-hexadecanoic acid ( $\left.B_{1}\right) ; n$-hexadecanoic acid, octadecanoic acid and docosanoic acid $\left(B_{2}\right)$. Aurantiamide acetate was the most active compound. The total phenol concentration expressed as gallic acid equivalents (GAE) was found to vary from 1.50 to $13.49 \mu \mathrm{g} / \mathrm{ml}$ in the extracts. The antioxidant activities were well correlated with the total phenol content $\left(R^{2}=0.946\right.$ for the TEAC method and $R^{2}=0.980$ for the DPPH free-radical scavenging assay).

Conclusions: Our results clearly reveal that the ethyl acetate extract from the stem bark of A. adianthifolia possesses antioxidant and antimicrobial principles. The antioxidant activity of this extract as well as that of compound 2 are being reported herein for the first time. These results provide promising baseline information for the potential use of this plant as well as compound 2 in the treatment of oxidative damage and infections associated with the studied microorganisms.
\end{abstract}

Keywords: Albizia adianthifolia, Antioxidant, Antimicrobial, Phenols, Fractionation, Aurantiamide acetate

\section{Background}

Albizia adianthifolia (Schumach) W. F. Wight (Mimosoideae), also known as A. chirindensis, A. fastigiata, is a big tree found in moist and tropical forest zones as well as areas that are transitional to woodland [1]. This plant is used in Central and West Africa for the treatment of skin diseases, bronchitis, inflamed eyes, tapeworm,

\footnotetext{
* Correspondence: jtamokou@yahoo.fr

'Department of Biochemistry, Laboratory of Microbiology and Antimicrobial Substances, Faculty of Science, University of Dschang, PO Box 67, Dschang, Cameroon

Full list of author information is available at the end of the article
}

headaches and sinusitis [2,3]. Various parts of $A$. adianthifolia are traditionally used to treat different diseases. The maceration of stem bark and root is used as an antidote against poison or applied in pomade on inflamed eye; the decoction of stem bark is drunk in the treatment of abdominal pains, typhoid fever and infections of urinary and respiratory tracts. Some biological activities exhibited by $A$. adianthifolia have been documented. Ethanolic extract of the root of this plant showed in vitro immunomodulatory activity on the Jurkart $\mathrm{T}$ cell line and haemolytic property against sheep erythrocytes [4]. These activities were attributed to the

\section{Biomed Central}


triterpenoidal saponins contained in this extract [4]. A. adianthifolia has also been reported to contain several flavonoids [5]. The root extracts of $A$. adianthifolia showed antibacterial, anti-inflammatory and anticholinesterase effects [6]. In many developing countries, the most infectious diseases are of microbial origin. With the advent of ever-increasing resistant bacterial and yeast strains, there has been a corresponding rise in the universal demand for natural antimicrobial therapeutics $[7,8]$. Microbial infections, especially due to Staphylococcus, Streptococcus and Pseudomonas species, and the presence of oxygen free radicals, are known impediments to wound healing [9]. Any agent capable of eliminating or reducing the number of microorganisms present in a wound, as well as reducing the level of reactive oxygen species (ROS), may facilitate the wound healing process. It then becomes necessary to search for new antimicrobial and antioxidant drugs, especially those that would be cheap and thus easily affordable by poor population. The present work was therefore designed to investigate the antioxidant and antimicrobial activities of ethyl acetate extract, fractions and compounds isolated from the stem bark of $A$. adianthifolia.

\section{Materials and methods}

Plant material

The stem bark of $A$. adianthifolia was collected from Mbouda (West Region of Cameroon) in January 2010. The plant material was identified at the Cameroon National Herbarium in Yaoundé where a voucher specimen ( $\mathrm{N}^{\circ}$ 19778/SRFCam) was deposited.

\section{Extraction, fractionation and isolation}

The stem bark of $A$. adianthifolia was dried at room temperature $\left(25 \pm 2^{\circ} \mathrm{C}\right)$ for three weeks and crushed. Four kilograms of obtained powder was macerated into 151 ethyl acetate (Merck) for two days and this process was repeated twice. After filtration, the filtrate was evaporated to dryness at $50^{\circ} \mathrm{C}$ under reduced pressure using a rotary evaporator. The dried crude extract $(1.75 \% \mathrm{w} / \mathrm{w})$ was stored at $+4^{\circ} \mathrm{C}$. A portion of $60 \mathrm{~g}$ of crude extract was then subjected to column chromatography $(22 \mathrm{~cm} \mathrm{x}$ $8 \mathrm{~cm}$ column) using $300 \mathrm{~g}$ of silica gel 40 (particle size 0.2-0.5 mm). The column was successively eluted with hexane (4200 ml), Hexane - EtOAc [19: 1 (3900 ml), 4 : 1 (4200 ml), $7: 3(4800 \mathrm{ml}), 3: 2(3300 \mathrm{ml}), 1: 1$ $(3300 \mathrm{ml})$ and $3: 7(6600 \mathrm{ml})]$ mixtures, ethyl acetate (4500 ml), ethyl acetate-methanol [19:1 (3000 ml), 17 : $3(3000 \mathrm{ml})$ and $7: 3(1500 \mathrm{ml})]$ mixtures and methanol $(3900 \mathrm{ml})$. One hundred and fifty four fractions of $300 \mathrm{ml}$ each were collected and combined on the basis of their thin layer chromatography (TLC) profiles to afford nine main fractions. Fractions 1-17, 18-25, 26-40, 4154, 55-78, 79-92, 93-124, 125-148 and 149-160 were referred to as $F_{1}, F_{2}, F_{3}, F_{4}, F_{5}, F_{6}, F_{7}, F_{8}$ and $F_{9}$ respectively. These fractions were tested for their antimicrobial/antioxidant activities and the most active fractions were further subjected to purification in order to isolate the active principles. Fraction $\mathrm{F}_{2}(2.80 \mathrm{~g})$ was loaded on a silica gel column (0.063-0.20 mm, $120 \mathrm{~g})$ eluted with hexane-EtOAc gradients and 37 subfractions of $100 \mathrm{ml}$ each were collected. Subfractions 1-7 obtained with hexane were purified on a sephadex LH20 column eluted with $\mathrm{CH}_{2} \mathrm{Cl}_{2}-\mathrm{MeOH}$ (9:1) to afford lupeol (45 mg) as yellow crystal. Subfractions 8-20 obtained with hexane-EtOAc (9:1) were purified by CC on sephadex LH-20 gel eluted with hexane-EtOAc $(8: 2)$ to give the mixture of fatty acids $B_{1}(33 \mathrm{mg})$ : oleic acid and $n$-hexadecanoic acid as yellowish crystal. Subfractions 21-32 obtained with hexane-EtOAc (1:1) were purified on a sephadex LH-20 column eluted with hexane-EtOAc (7:3) to yield the mixture of fatty acids $\mathrm{B}_{2}$ (46 mg): $n$-hexadecanoic acid, octadecanoic acid and docosanoic acid as yellowish crystal. Aurantiamide acetate $\left(30 \mathrm{mg}\right.$ ) was obtained from fraction $\mathrm{F}_{4}$ (17.20 g, eluted with $\mathrm{CH}_{2} \mathrm{Cl}_{2}$-EtoAc 19:1) after purification by preparative TLC. Fraction $F_{5}(10.30 \mathrm{~g})$ yielded two individual minor compounds (detected only on TLC) and a complex mixture.

\section{Identification of the isolated compounds}

The structures of the isolated compounds were established using spectroscopic analysis, especially, NMR spectra in conjunction with $2 \mathrm{D}$ experiments and by direct comparison with published information $[10,11]$ and authentic specimens obtained in our laboratory for some cases. Melting points (uncorr.) were determined on a Kofler apparatus. ${ }^{1} \mathrm{H}, 2 \mathrm{D}{ }^{1} \mathrm{H}_{-}{ }^{1} \mathrm{H}$ COSY, ${ }^{13} \mathrm{C}, 2 \mathrm{D}$ HMQC and $\mathrm{HMBC}$ spectra were recorded with a Bruker Avance $500 \mathrm{MHz}$ spectrometer. Optical spectra were recorded with a NICOLET 510 P FT-IR spectrometer, a UV-2101 PC spectrometer, and a Perkin- Elmer 241 polarimeter. Column chromatography was run on Merck silica gel 60 and gel permeation on sephadex LH-20, while TLC were carried out either on silica gel $\mathrm{GF}_{254}$ pre-coated plates (analytical TLC) or on silica gel $60 \mathrm{PF}_{254}$ containing gypsum (preparative TLC), with detection accomplished by spraying with $50 \% \mathrm{H}_{2} \mathrm{SO}_{4}$ followed by heating at $100^{\circ} \mathrm{C}$, or by visualizing with an UV lamp at 254 and $366 \mathrm{~nm}$.

The mixtures of fatty acids were identified by comparison of their mass spectra with those available from the equipment database (Wiley 7 Nist 05.L) and from the literature. Gas chromatography-mass spectrometry (GC-MS) data were obtained with an Argilent $6890 \mathrm{~N}$ Network GC system/5975 Inert x L Mass selective Detector at $70 \mathrm{eV}$ and $20^{\circ} \mathrm{C}$. The GC column was a CP- Sil 8 CB LB, fused silica capillary column $(0.25 \mathrm{~mm}$ x $30 \mathrm{~m}$, 
film thickness $0.25 \mu \mathrm{m})$. The initial temperature was $50^{\circ} \mathrm{C}$ for $1 \mathrm{~min}$, and then heated at $10^{\circ} \mathrm{C} / \mathrm{min}$ to $300^{\circ} \mathrm{C}$. The carrier gas was helium at a flow rate of $1.20 \mathrm{ml} / \mathrm{min}$. Mass spectral data were used to identify fatty acid fractions.

\section{Determination of total phenol content}

Total phenol content was determined spectrophotometrically in the extracts by using Folin-Ciocalteu method as previously described [12]. The Folin-Ciocalteu reagent was prepared by mixing $5 \mathrm{~g}$ sodium tungstate, $1.25 \mathrm{~g}$ sodium molybdate, $2.50 \mathrm{ml}$ of $85 \%$ phosphoric acid, $10 \mathrm{ml}$ 20\% hydrochloric acid, $7.50 \mathrm{~g}$ lithium sulfate, two drops of bromine and deionized water to a final volume of $50 \mathrm{ml}$. Further, stock solutions of $20 \%$ sodium carbonate and $400 \mathrm{mg} / \mathrm{l}$ gallic acid were added. For each sample, 20, 10 and $1 \mu \mathrm{l}$ of $10 \mathrm{mg} / \mathrm{ml}$ ethanolic extract or $20 \mu \mathrm{l}$ of $1 \mathrm{mg} / \mathrm{ml}$ ethanolic isolated compounds were added to $640 \mu \mathrm{l}$ distilled water and $200 \mu \mathrm{l}$ freshly prepared Folin-Ciocalteu reagent, followed by incubation in the dark for $5 \mathrm{~min}$.

Then, $150 \mu \mathrm{l}$ of $20 \%$ sodium carbonate solution were added and samples were incubated in the dark for $30 \mathrm{~min}$. The solution turned deep blue. The final concentration of the tested samples in the assayed solution was $100 \mu \mathrm{g} / \mathrm{ml}$ and $10 \mu \mathrm{g} / \mathrm{ml}$ for the extracts and isolated compounds respectively. At the same time, gallic acid standards of $6.25,12.50,25,50$ and $75 \mu \mathrm{g} / \mathrm{ml}$ final concentration solutions were reacted with the FolinCiocalteu reagent in the same way as the samples. The UV-vis spectra of all the samples were recorded against the reference solution (zero gallic acid) and the absorbance was monitored at $725 \mathrm{~nm}$. The measurements were done in triplicate. For the gallic acid standards, a calibration curve (Pearson's correlation coefficient: $\left.R^{2}=0.992\right)$ was constructed and the total level of phenolics for each sample was determined in terms of gallic acid equivalents.

\section{Antimicrobial assay \\ Micro-organisms}

The microorganisms used in this study consisted of six bacteria (Enterococcus faecalis ATCC10541, Staphylococcus aureus ATCC25923, Pseudomonas aeruginosa ATCC27853, Escherichia coli ATCC11775, Klebsiella pneumoniae ATCC13883, Salmonella typhi ATCC6539) and seven fungi (Candida albicans ATCC9002, ATCC2091 and 24433, Candida parapsilosis ATCC22019, C. lusitaniae ATCC200950, C. tropicalis ATCC750, C. krusei ATCC6258); all of which are reference strains obtained from American Type Culture Collection. Also, included were two clinical isolates of bacteria (Proteus mirabilis, Shigella flexneri) collected from Pasteur Centre (Yaoundé-
Cameroon) and two fungal strains (C. glabbrata IP35, Cryptococcus neoformans IP95026) obtained from Pasteur Institute (IP, Paris-France). The bacterial and yeast strains were grown at $35^{\circ} \mathrm{C}$ and maintained on nutrient agar (NA, Conda, Madrid, Spain) and Sabouraud Dextrose Agar (SDA, Conda) slants respectively.

\section{Determination of the minimum inhibitory concentration (MIC) and minimum microbicidal concentration (MMC)}

MIC was determined by broth micro dilution method as previously reported [13]. The inocula of microorganisms were prepared from $24 \mathrm{~h}$ old broth cultures. The absorbance was read at $600 \mathrm{~nm}$ and adjusted with sterile physiological solution to match that of a 0.5 McFarland standard solution. From the prepared microbial solutions, other dilutions with sterile physiological solution were prepared to give a final concentration of $10^{6}$ colony-forming units (CFU) per millilitre for bacteria and $2 \times 10^{5}$ spores per millilitre for yeasts. Stock solutions of the extracts (crude extract and fractions) were prepared in 5\% aqueous tween 20 (Fisher chemicals) at concentrations of $50 \mathrm{mg} / \mathrm{ml}$ (for crude extract and fractions) and $1.60 \mathrm{mg} / \mathrm{ml}$ (for pure compounds). The two-fold serial dilutions in concentrations of the extracts $(25-0.048 \mathrm{mg} / \mathrm{ml})$ and pure compounds (800$0.39 \mu \mathrm{g} / \mathrm{ml}$ ) were prepared in Mueller Hinton Broth (MHB) (Conda, Madrid, Spain) for bacteria and Sabouraud Dextrose Broth (SDB) (Conda, Madrid, Spain) for yeasts. For every experiment, a sterility check (5\% aqueous tween 20 and medium), negative control (5\% aqueous tween 20, medium and inoculum) and positive control (5\% aqueous tween 20 , medium, inoculum and water-soluble antibiotics) were included. In general, the 24-macro well plates (Nunclon, Roskilde, Danmark) were prepared by dispensing into each well $880 \mu \mathrm{l}$ of an appropriate medium, $100 \mu \mathrm{l}$ of test substances and $20 \mu \mathrm{l}$ of the inoculum $\left(10^{6} \mathrm{CFU} / \mathrm{ml}\right.$ for bacteria and $5 \times 10^{5}$ spores $/ \mathrm{ml}$ for yeasts). The content of each well was mixed thoroughly with a multi-channel pipette and the macro-well plates were covered with the sterile sealer and incubated at $35{ }^{\circ} \mathrm{C}$ for $24 \mathrm{~h}$ (for bacteria) and $48 \mathrm{~h}$ (for yeasts) under
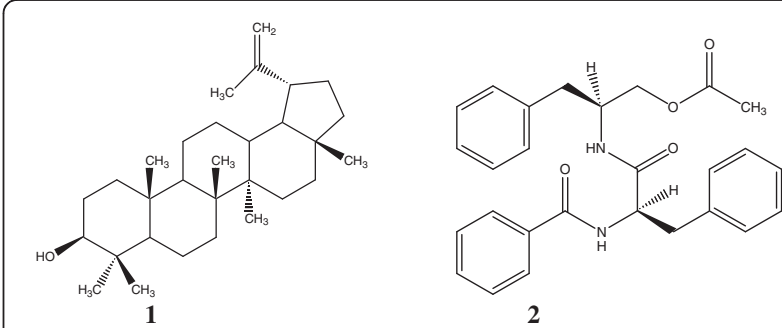

Figure 1 Chemical structures of lupeol (1) and aurantiamide acetate (2) 
Table 1 Minimum inhibitory concentrations of the crude extract, fractions and compounds isolated from A. adianthifolia

\begin{tabular}{|c|c|c|c|c|c|c|c|c|c|c|}
\hline \multirow{2}{*}{$\begin{array}{l}\text { Name of microorganism } \\
\text { Bacteria }\end{array}$} & \multicolumn{10}{|c|}{ Minimum inhibitory concentrations $(\mathrm{mg} / \mathrm{ml})$} \\
\hline & Crude extract & $F_{2}$ & $F_{3}$ & $\mathrm{~F}_{4}$ & $F_{5}$ & $\mathrm{~B}_{1}$ & $\mathrm{~B}_{2}$ & 1 & 2 & References $^{\mathrm{a}}$ \\
\hline Pseudomonas aeruginosa & 0.19 & na & / & 0.19 & 1.56 & na & na & na & 0.10 & 0.025 \\
\hline Proteus mirabilis & 0.39 & 3.12 & 1.56 & 0.39 & 0.19 & 0.10 & 0.40 & 0.20 & 0.05 & 0.10 \\
\hline Klebsiella pneumoniae & 0.78 & na & / & 0.39 & 0.78 & na & na & na & 0.05 & 0.025 \\
\hline Shigella flexneri & 0.19 & 6.25 & 6.25 & 0.19 & 0.39 & 0.05 & 0.10 & 0.10 & 0.05 & 0.05 \\
\hline Salmonella typhi & 0.09 & 3.12 & 3.12 & 0.04 & 0.39 & 0.20 & 0.40 & na & 0.10 & 0.05 \\
\hline Escherichia coli & 0.78 & na & / & 0.78 & 1.56 & na & na & na & 0.05 & 0.025 \\
\hline Staphylococcus aureus & 0.09 & 3.12 & 3.12 & 0.09 & 0.78 & 0.20 & 0.80 & 0.20 & 0.05 & 0.05 \\
\hline Enterococcus faecalis & 0.78 & 3.12 & 3.12 & 0.04 & 0.39 & 0.40 & 0.20 & 0.40 & 0.10 & 0.012 \\
\hline \multicolumn{11}{|l|}{ Yeasts } \\
\hline Candida albicans ATCC 9002 & 1.56 & na & / & 1.56 & 3.12 & 0.20 & 0.40 & 0.40 & 0.025 & 0.001 \\
\hline Candida albicans ATCC 2091 & 3.12 & na & / & 0.39 & 0.78 & / & / & / & 0.025 & 0.0015 \\
\hline Candida albicans ATCC 24433 & 0.78 & 3.12 & 3.12 & 0.78 & 1.56 & / & / & / & 0.05 & 0.001 \\
\hline Candida parapsilosis & 3.12 & na & 1.56 & 3.12 & 6.25 & / & / & 0.20 & 0.006 & 0.01 \\
\hline Candida tropicalis & 6.25 & na & na & 6.25 & na & 0.40 & 0.10 & / & 0.006 & 0.006 \\
\hline Candida krusei & 1.56 & na & na & 0.78 & na & / & / & 0.40 & 0.012 & 0.003 \\
\hline Candida glabbrata & 1.56 & na & na & 1.56 & na & / & / & / & 0.025 & 0.012 \\
\hline Candida lusitaniae & 0.39 & 1.56 & 1.56 & 0.09 & 0.78 & 0.10 & 0.20 & 0.10 & 0.05 & 0.001 \\
\hline Cryptococcus neoformans & 0.78 & 6.25 & 3.12 & 0.39 & 1.56 & 0.20 & 0.40 & 0.20 & 0.006 & 0.001 \\
\hline
\end{tabular}

The results are the mean values of triplicate tests measured after $24-48 \mathrm{~h}$ incubation at $35^{\circ} \mathrm{C} ;$ na: not active; /: not tested; ${ }^{a}$ gentamicin and nystatin were used as reference antibiotics for bacteria and yeasts respectively; $B_{1}$ Oleic acid and $n$-hexadecanoid acid; $B_{2:} n$-hexadecanoic acid, octadecanoic acid and docosanoic acid; 1: lupeol; 2: aurantiamide acetate.

shaking by using a plate shaker (Flow Laboratory, Germany) at $300 \mathrm{rpm}$. Microbial growth in each well was determined by observing and comparing the test wells with the positive and negative controls. The absence of microbial growth was interpreted as the antibacterial or antifungal activities. The MIC was the lowest concentration of the test substances that prevented visible growth of micro-organisms. Minimum Bactericidal Concentrations (MBCs) or Minimum Fungicidal Concentrations (MFCs) were determined by plating $10 \mu \mathrm{l}$ from each negative well and from the positive growth control on Mueller Hinton Agar (for bacteria) and Sabouraud Dextrose Agar (for yeasts). MBCs or MFCs were defined as the lowest concentration yielding negative subcultures or only one colony. All the experiments were performed in triplicate. Gentamicin and nystatin at the concentration ranging between 400 and $0.78 \mu \mathrm{g} / \mathrm{ml}$ served as positive controls for antibacterial and antifungal activities respectively.

\section{Antioxidant assay}

\section{DPPH free radical scavenging assay}

The free radical scavenging activity of the extracts as well as their isolated compounds was evaluated according to described methods [14]. Briefly, the test samples, prior dissolved in DMSO (SIGMA) beforehand, were mixed with a $20 \mathrm{mg} / \mathrm{l}$ 2,2-diphenyl-1-picryl-hydrazyl (DPPH) methanol solution, to give final concentrations of 10, 50, 100, 500 and $1000 \mu \mathrm{g} / \mathrm{ml}$. After $30 \mathrm{~min}$ at room temperature, the absorbance values were measured at $517 \mathrm{~nm}$ and converted into percentage of antioxidant activity. L-ascorbic acid was used as a standard control. The percentage of decolouration of DPPH (\%) was calculated as follows:

$\%$ decolouration of DPPH $=\frac{(\text { Absorbance of control }- \text { Absorbance of test sample }) \text { X100 }}{\text { Absorbance of control }}$ 
The percentage of decolouration of DPPH (\%) was plotted against the test sample. Also, the percentage of decolouration of DPPH was converted in probits. The probit values were plotted against the logarithmic values of concentrations of the test samples and a linear regression curve was established in order to calculate the $\mathrm{EC}_{50}$ $(\mu \mathrm{g} / \mathrm{ml})$, which is the amount of sample necessary to decrease by $50 \%$ the absorbance of DPPH. All the analysis were carried out in triplicate.

\section{Trolox equivalent antioxidant capacity (TEAC) assay}

The TEAC test was done as previously described [15] with slight modifications. In a quartz cuvette, to $950 \mu \mathrm{l}$ acetate buffer $(\mathrm{pH}=5.0,100 \mathrm{mM})$, the following were added: $20 \mu$ laccase (1 mM stock solution), $20 \mu \mathrm{l}$ test sample, $10 \mu \mathrm{l}$ ABTS (2,2'-azinobis(3-ethylbenzothiazoline6-sulfonic acid)) (74 mM stock solution). The sample concentrations in the assay mixture were 200, 100, $10 \mu \mathrm{g} /$ $\mathrm{ml}$ for the extracts and $20 \mu \mathrm{g} / \mathrm{ml}$ for the isolated compounds. The content of the generated $\mathrm{ABTS}^{\bullet+}$ radical was measured at $420 \mathrm{~nm}$ after $230 \mathrm{~s}$ reaction time and was converted to gallic acid equivalents by the use of a calibration curve (Pearson's correlation coefficient: $\left.R^{2}=0.997\right)$ constructed with $0,4,10,14,28,56,70 \mu \mathrm{M}$ gallic acid standards rather than Trolox. Experiments were done in triplicate.

\section{Statistical analysis}

Statistical analysis was carried out using Statistical Package for Social Science (SPSS, version 12.0). The experimental results were expressed as the mean \pm Standard Deviation (SD). Group comparisons were performed using One Way ANOVA followed by Waller-Duncan Post Hoc test. A $\mathrm{p}$ value of 0.05 was considered statistically significant.

\section{Results}

\section{Phytochemical analysis}

Two known compounds: lupeol (1) and aurantiamide acetate $(2)$ and two main mixtures of fatty acids $\left(B_{1}\right.$ : oleic acid and $n$-hexadecanoic acid; $\mathrm{B}_{2}: n$-hexadecanoic acid, octadecanoic acid and docosanoic acid were isolated from ethyl acetate extract of $A$. adianthifolia stem bark. The structures of compounds $\mathbf{1}$ and $\mathbf{2}$ are presented on Figure 1.

\section{Antimicrobial activity}

In this study, the antibacterial and antifungal activities of the crude extract, fractions and the isolated compounds were evaluated. The broth micro dilution method was applied to 17 microorganisms including fungi from Candida and Cryptococcus genus, gram-positive and gram negative bacteria. The results summarized in Tables 1 and 2 showed that the crude extract, fractions $\mathrm{F}_{2}-\mathrm{F}_{5}$,

Table 2 Minimum microbicidal concentrations of the crude extract, fractions and compounds isolated from A. adianthifolia

\begin{tabular}{|c|c|c|c|c|c|c|c|c|c|c|}
\hline \multirow{2}{*}{$\begin{array}{l}\text { Name of microorganism } \\
\text { Bacteria }\end{array}$} & \multicolumn{10}{|c|}{ Minimum microbicidal concentrations (mg/ml) } \\
\hline & Crude extract & $\mathbf{F}_{2}$ & $F_{3}$ & $\mathbf{F}_{4}$ & $F_{5}$ & $\mathrm{~B}_{1}$ & $\mathrm{~B}_{2}$ & 1 & 2 & References $^{\mathrm{a}}$ \\
\hline Pseudomonas aeruginosa & 0.39 & na & / & 0.39 & 3.12 & na & na & na & 0.10 & 0.025 \\
\hline Proteus mirabilis & 0.78 & 3.12 & 3.12 & 0.39 & 0.39 & 0.20 & 0.80 & 0.20 & 0.05 & 0.10 \\
\hline Klebsiella pneumoniae & 1.56 & na & / & 0.39 & 1.56 & na & na & na & 0.05 & 0.025 \\
\hline Shigella flexneri & 0.39 & 6.25 & 6.25 & 0.39 & 0.39 & 0.10 & 0.20 & 0.20 & 0.05 & 0.05 \\
\hline Salmonella typhi & 0.19 & 3.12 & 3.12 & 0.09 & 0.39 & 0.40 & 0.80 & na & 0.10 & 0.05 \\
\hline Escherichia coli & 1.56 & na & / & 1.56 & 1.56 & na & na & na & 0.05 & 0.025 \\
\hline Staphylococcus aureus & 0.39 & 3.12 & 3.12 & 0.09 & 1.56 & 0.20 & 0.80 & 0.20 & 0.05 & 0.05 \\
\hline Enterococcus faecalis & 0.78 & 3.12 & 3.12 & 0.09 & 0.39 & 0.40 & 0.20 & 0.40 & 0.10 & 0.012 \\
\hline \multicolumn{11}{|l|}{ Yeasts } \\
\hline Candida albicans ATCC 9002 & 3.12 & na & / & 3.12 & 6.25 & $>0.80$ & 0.80 & 0.40 & 0.025 & 0.001 \\
\hline Candida albicans ATCC 2091 & 6.25 & na & / & 1.56 & 1.56 & / & / & / & 0.025 & 0.0015 \\
\hline Candida albicans ATCC 24433 & 1.56 & 3.12 & 3.12 & 1.56 & 3.12 & / & / & / & 0.05 & 0.001 \\
\hline Candida parapsilosis & 6.25 & na & 1.56 & 3.12 & 6.25 & / & / & 0.20 & 0.012 & 0.01 \\
\hline Candida tropicalis & 6.25 & na & na & 6.25 & na & $>0.80$ & 0.20 & / & 0.025 & 0.006 \\
\hline Candida krusei & 3.12 & na & na & 1.56 & na & / & / & 0.40 & 0.012 & 0.03 \\
\hline Candida glabbrata & 3.12 & na & na & 1.56 & na & / & / & / & 0.05 & 0.012 \\
\hline Candida lusitaniae & 0.78 & 3.12 & 3.12 & 0.19 & 0.78 & $>0.80$ & 0.40 & 0.20 & 0.05 & 0.001 \\
\hline Cryptococcus neoformans & 0.78 & 6.25 & 6.25 & 0.78 & 3.25 & $>0.80$ & 0.80 & 0.20 & 0.006 & 0.001 \\
\hline
\end{tabular}

The results are the mean values of triplicate tests measured after $24-48 \mathrm{~h}$ incubation at $35^{\circ} \mathrm{C} ;$ na: not active; /: not tested; ${ }^{\circ}$ gentamicin and nystatin were used as reference antibiotics for bacteria and yeasts respectively; $B_{1}$ : Oleic acid and $n$-hexadecanoid acid; $B_{2:} n$-hexadecanoic acid, octadecanoic acid and docosanoic acid; 1: lupeol; 2: aurantiamide acetate. 
mixtures of fatty acids $B_{1}$ and $B_{2}$, compounds 1 and 2 prevented the growth of most of the tested microorganisms. The MIC values obtained varied from 0.006 to $6.25 \mathrm{mg} / \mathrm{ml}$ and 0.04 to $6.25 \mathrm{mg} / \mathrm{ml}$ for yeasts and bacteria respectively (Table 1 ). The lowest MIC value $(0.006 \mathrm{mg} / \mathrm{ml})$ was recorded with compound 2 on Candida parapsilosis, Candida tropicalis and Cryptococcus neoformans. The inhibition effects of the crude extract, fraction $\mathrm{F}_{4}$ and compound 2 were observed on all the tested microorganisms (100\%). Those of fractions $\mathrm{F}_{2}, \mathrm{~F}_{3}$, $\mathrm{F}_{5}, \mathrm{~B}_{1}, \mathrm{~B}_{2}$ and compound $\mathbf{1}$ were respectively noted on 8 (47.5\%), 9 (52.94\%), 14 (82.35\%), 9 (52.94\%), 9 (52.94\%) and $9(52.94 \%)$ of the 17 tested microbial species. The results of the MMC determination (Table 2) also indicated a detectable MMC value within the tested interval for crude extract, fractions and compounds on several tested microorganisms. Compound $\mathbf{2}$ was the most active sample. Moreover, its MIC values were often equal to or lower than those of reference drugs gentamicin and nystatin. Proteus mirabilis, Shigella flexneri, Staphylococcus aureus and Enterococcus faecalis were in general found to be the most sensitive bacteria species while Candida lusitaniae and Cryptococcus neoformans showed the best susceptibility amongst the yeasts tested (Table 1). The MICs were generally four-fold less than the corresponding MMCs (Tables 1 and 2). The crude extract was more effective on bacteria as compare to fungi. Fractionation enhanced the antimicrobial activity of the crude extract in fraction $\mathrm{F}_{4}$. However, these activities decreased in fractions $\mathrm{F}_{2}, \mathrm{~F}_{3}$ and $\mathrm{F}_{5}$. No activity (MIC $>12.50 \mathrm{mg} / \mathrm{ml}$ ) was noticed in fractions $F_{1}, F_{6}$, $F_{7}, F_{8}$ and $F_{9}$ for all the microorganisms tested (not shown).

\section{Total phenol content}

The Folin-Ciocalteu assay is one of the oldest methods developed to determine the content of total phenols [16]. In this work, the total phenol content of crude extract and fractions from $A$. adianthifolia stem bark was analyzed. As shown in Figure 2, the total phenol content expressed as gallic acid equivalents (GAE) was found to vary from 1.50 to $13.49 \mu \mathrm{g} / \mathrm{ml}$ in the extracts. Also, the fractionation increased the total phenol content of the crude extract (GAE: $3.95 \mu \mathrm{g} / \mathrm{ml}$ ) in fractions $\mathrm{F}_{2}, \mathrm{~F}_{3}$ and

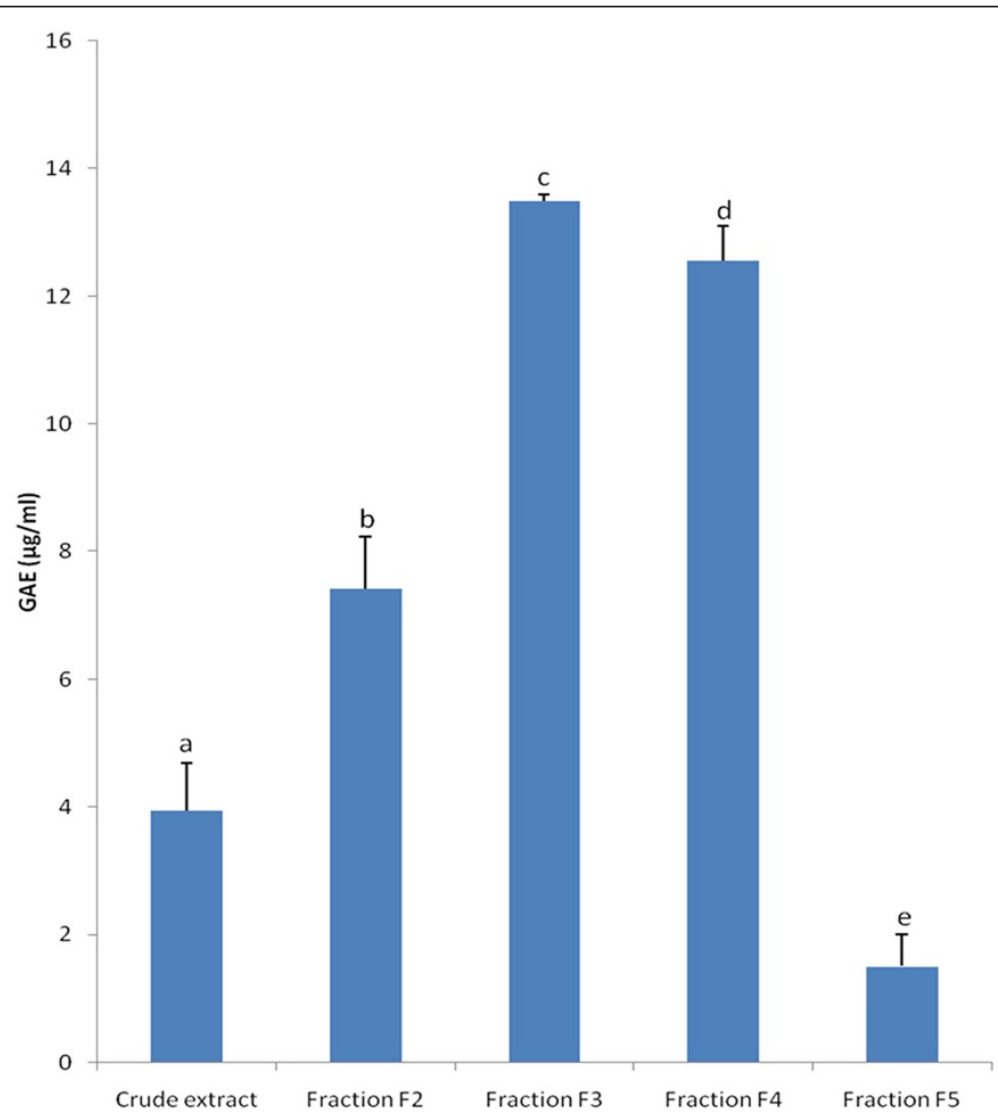

Figure 2 Total phenol content expressed as gallic acid equivalents (GAE; $\mu \mathrm{g} / \mathrm{ml})$ in crude extract and fractions. Bars represent the mean \pm SD of three independent experiments carried out in triplicate. Letters a - e indicate significant differences between samples according to one way ANOVA and Waller Duncan test; $p<0.05$. 
$\mathrm{F}_{4}$ (GAE: $7.42,13.49$ and $12.56 \mu \mathrm{g} / \mathrm{ml}$ respectively); but the amount was low in fraction $F_{5}(\mathrm{GAE}: 1.50 \mu \mathrm{g} / \mathrm{ml})$.

\section{Antioxidant activity}

Both with DPPH and TEAC methods, aurantiamide acetate $\quad\left(\mathrm{EC}_{50}=9.51 \mu \mathrm{g} / \mathrm{mL} ; \quad \mathrm{TEAC}=78.81 \mu \mathrm{g} / \mathrm{mL}\right)$ showed the highest antioxidant activity (AOA) followed in decreasing order by fraction $3\left(\mathrm{EC}_{50}=26.30 \mu \mathrm{g} / \mathrm{mL}\right.$; $\mathrm{TEAC}=61.60 \mu \mathrm{g} / \mathrm{mL})$, fraction $4\left(\mathrm{EC}_{50}=30.11 \mu \mathrm{g} / \mathrm{mL}\right.$; $\mathrm{TEAC}=55.95 \mu \mathrm{g} / \mathrm{mL})$, fraction $2\left(\mathrm{EC}_{50}=32.35 \mu \mathrm{g} / \mathrm{mL}\right.$; $\mathrm{TEAC}=50.32 \mu \mathrm{g} / \mathrm{mL})$, crude extract $\left(\mathrm{EC}_{50}=70.11 \mu \mathrm{g} / \mathrm{mL}\right.$; $\mathrm{TEAC}=46.72 \mu \mathrm{g} / \mathrm{mL})$ and fraction $5\left(\mathrm{EC}_{50}=77.75 \mu \mathrm{g} / \mathrm{mL}\right.$; $\mathrm{TEAC}=39.10 \mu \mathrm{g} / \mathrm{mL}$ ) (Figures 3 and 4 ). However, the AOA of aurantiamide acetate $\left(\mathrm{EC}_{50}=9.51 \mu \mathrm{g} / \mathrm{mL}\right)$ was significantly $(\mathrm{p}<0.05)$ lower than that of L-ascorbic acid $\left(\mathrm{EC}_{50}=6.81 \mu \mathrm{g} / \mathrm{mL}\right)$ used as reference antioxidant compound (Figure 3). Fractionation enhanced the AOA of the crude extract in fractions $\mathrm{F}_{2}, \mathrm{~F}_{3}$ and $\mathrm{F}_{4}$; but this activity was low in fractions $F_{5}$ (Figures 3 and 4). Fractions $F_{1}$ and $\mathrm{F}_{6}-\mathrm{F}_{9}$ were not active (not shown).

\section{Correlation between the antioxidant capacity and the total phenol content}

The AOAs were well correlated with the total phenol content: $R^{2}=0.946$ for the TEAC method and $R^{2}=0.980$ for the DPPH free-radical scavenging assay (Figure 5).

\section{Discussion}

The findings of the present study showed that there were differences between the antimicrobial/antioxidant activities of crude extract and those of fractions. Fractions $\mathrm{F}_{2}$-F4 (for antioxidant activity) and $\mathrm{F}_{4}$ (for antimicrobial activity) were more active than the crude extract indicating that fractionation enhanced the considered biological activities of these fractions. This may be due to the exclusion by fractionation of some constituents of the extract which may tend to dilute the active

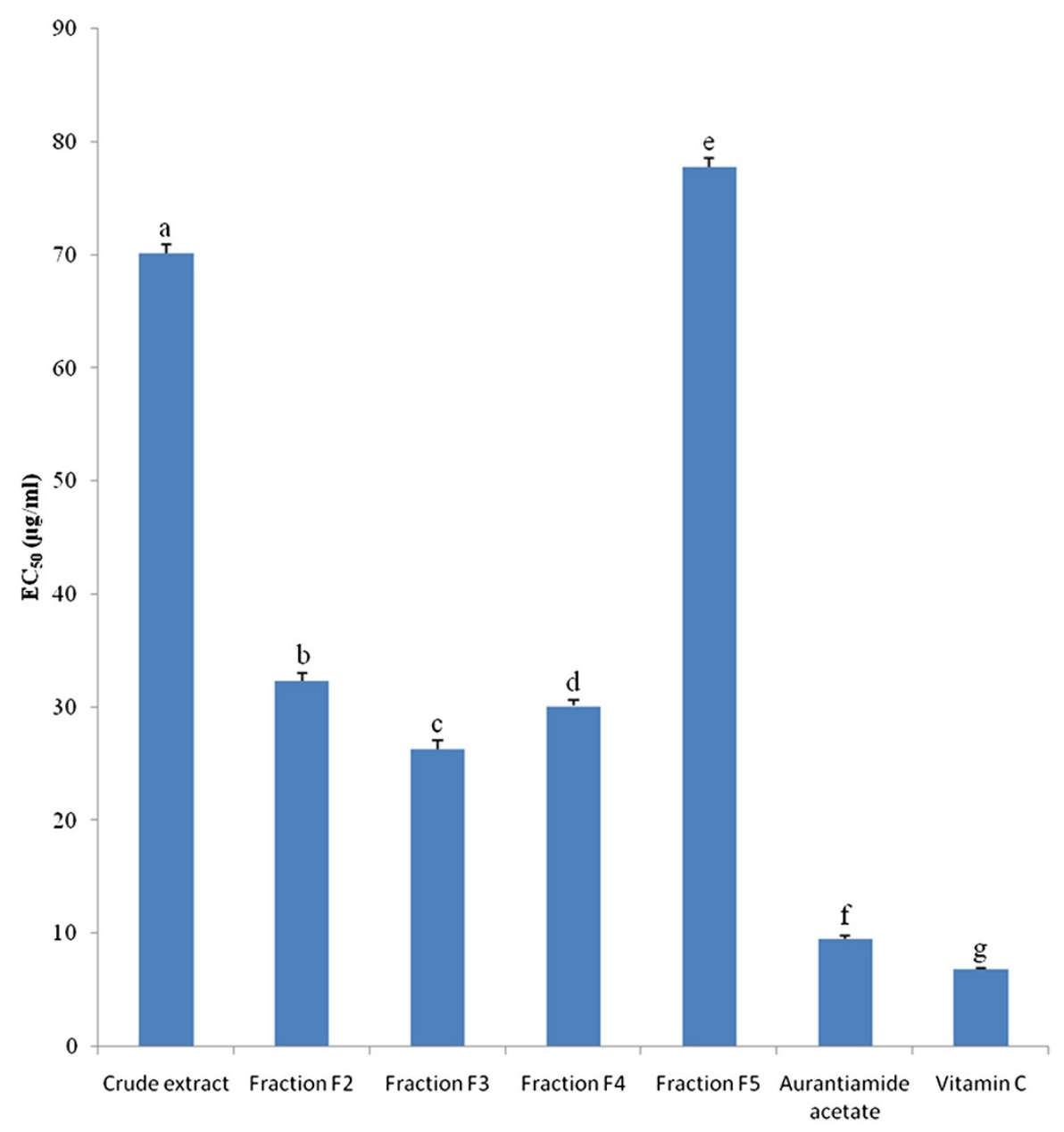

Figure 3 Equivalent concentrations of test samples scavenging $50 \%$ of DPPH radical $\left(\mathrm{EC}_{50}\right)$. Bars represent the mean $\pm \mathrm{SD}$ of three independent experiments carried out in triplicate. Letters a - $\mathrm{g}$ indicate significant differences between samples according to one way ANOVA and Waller Duncan test; $p<0.05$. 


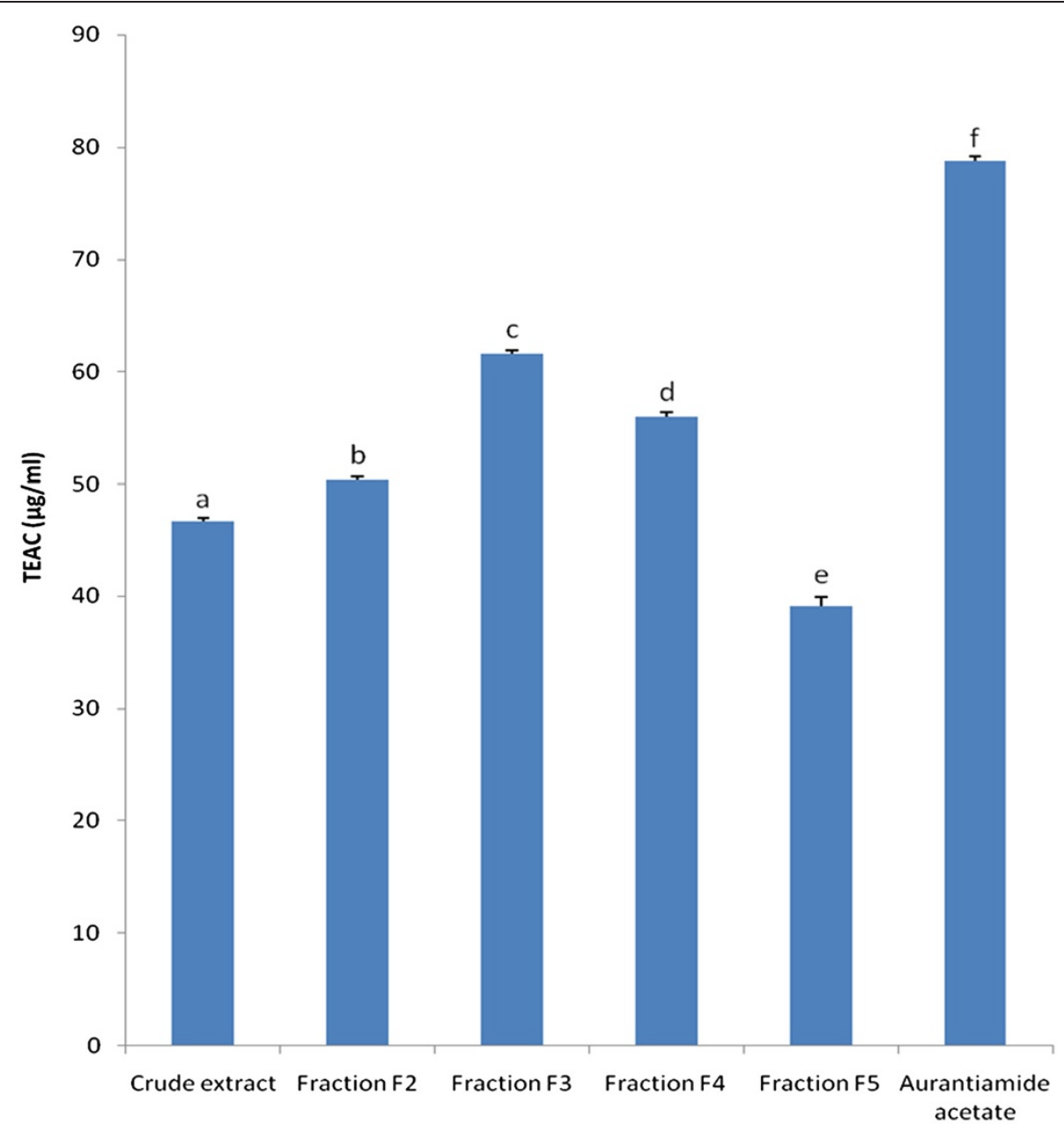

Figure 4 Gallic acid equivalent antioxidant capacity (TEAC; $\boldsymbol{\mu g} / \mathbf{m l}$ ) of tested samples. Bars represent the mean \pm SD of three independent experiments carried out in triplicate. Letters a-f indicate significant differences between samples according to one way ANOVA and Waller Duncan test; $p<0.05$.

principle and reduce its activity. On the other hand, fractionation may have increased the concentrations and the activities of antimicrobial/antioxidant principles in these fractions. Our results partially justify the traditional use of this plant for the treatment of skin diseases, bronchitis, typhoid fever and infections of urinary and respiratory tracts that can be caused by the tested microorganisms. The data showed that the response in
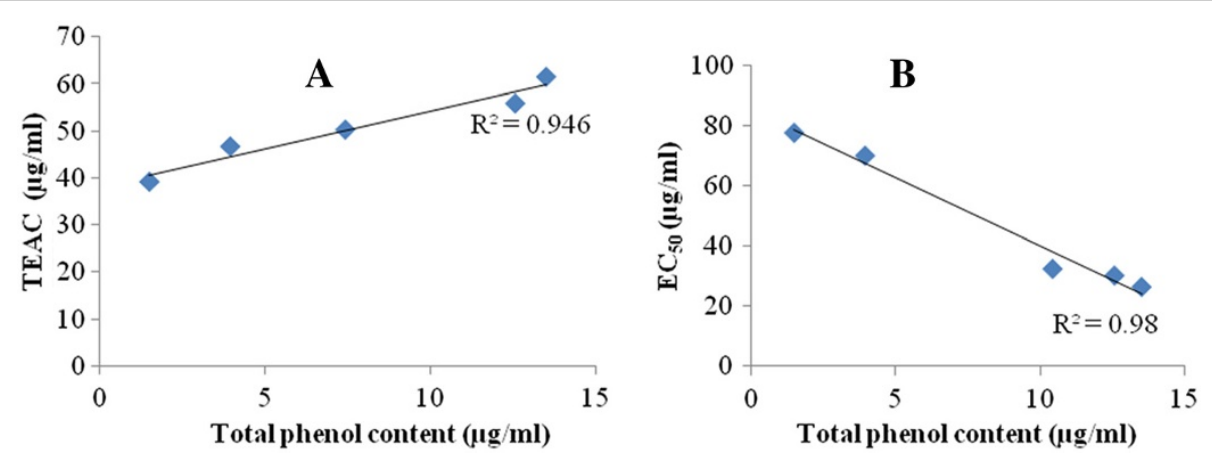

Figure 5 Positive correlations between the TEAC (A) or $\mathrm{EC}_{50}(\mathbf{B})$ and total phenol content. Results represent the mean $\pm \mathrm{SD}$ of three independent experiments performed in triplicate. TEAC: gallic acid equivalent antioxidant capacity, $\mathrm{EC}_{50}$ : equivalent concentration of the test samples scavenging $50 \%$ of DPPH radical. 
terms of susceptibility to tested plant extracts/isolated compounds varied among the strains. These variations may be due to genetic differences between the strains. It was also found that MMC values (Table 2) obtained were generally less than four-fold greater than the MICs (Table 1) on the corresponding microbial species, suggesting that the killing effects of the crude extract and the isolated compounds could be expected on most of the tested micro-organisms $[13,17,18]$. This is very interesting in the perspective of developing antimicrobial drugs from the tested samples. Subfractions $B_{1}$ and $B_{2}$ showed antimicrobial activity against yeasts and bacteria. This is not surprising since some lipid fractions and individual fatty acids have shown this type of biological activities [19,20]. Compounds $\mathbf{1}$ and $\mathbf{2}$ displayed both antibacterial and antifungal activities. Comparable results were reported [21,22].

The antioxidant activities of ethyl acetate extract of $A$. adianthifolia stem bark corroborate those reported on the stem bark of Albizia julibrissin [23]. Numerous examples of the application of the Folin-Ciocalteu assay to characterize natural products may be found in literature. In most cases, total phenols determined by this method are correlated with the antioxidant capacities confirming the value of the Folin-Ciocalteu test [24]. A new enzymatic method involoving the use of horseradish peroxidase and 4-aminoantipyrine has recently been used in a comparative study of total polyphenol content of tea. Significant differences were found in the results obtained by the Folin-Ciocalteu and enzymatic methods indicating that the enzymatic method needs further standardization [25]. In addition to the compound 2, phenolic and other nitrogenous compounds were previously isolated from $A$. adianthifolia [4,5]. Phenolic and nitrogenous compounds are known to be potential antioxidant due to their ability to scavenge free radicals and active oxygen species such as singlet oxygen, superoxide anion radical and hydroxyl radicals [26,27]. Therefore, the presence of such compounds could be responsible for the antioxidant activity found in the crude extract and fractions. To the best of our knowledge, this is the first systematic screening for the quantification of phenols and antioxidant activity of the crude extract, fractions and compounds from $A$. adianthifolia.

The overall results of this study can be considered as very promising in the perspective of new drugs discovery from plant sources, when considering the medical importance of tested microorganisms as well as the high level of neurodegenerative diseases associated with oxidative stress. Pseudomonas aeruginosa has emerged as one of the most problematic gram-negative pathogens, with the alarmingly high antibiotics resistance rates [28,29]. Even with the most effective antibiotic (carbapenems) against this pathogen, the resistance rates were detected as 1520.40\% amongst 152 Pseudomonas aeruginosa strains [29]. This pathogen was found to be sensitive to the crude extract. Staphylococcus aureus is a major cause of community and hospital-associated infection with an estimated mortality of around $7-10 \%$ [30]. About $77 \%$ of immunedeficient patients' death is attributable to microscopic fungi, such as Candida species and Cryptococcus neoformans [31]. The prevalence of the typhoid fever caused by Salmonella typhi is increased in developing country nowadays [13]. Such findings trace the importance of discovery new substances against which these organisms are sensitive. Generally, at least one sample tested in this study prevented the growth of each microbial strain.

\section{Conclusions}

The results of the present study provide an important basis for use of $A$. adianthifolia in the treatment of oxidative damages and infections associated with the studied microorganisms. The ethyl acetate extract, fractions F2, F3 and F4 as well as aurantiamide acetate found to be the most active samples in this study could be useful for the development of new antimicrobial and antioxidant substances.

\section{Competing interests}

The authors declare that they have no competing interests.

\section{Authors' contributions}

JDT designated the study, did the extraction/fractionation of the extract and the biological tests under the supervision of JRK. PKL helped to draft the manuscript and in the biological assays. DJMS, MT and PT did the isolation and structure elucidation part and helped in manuscript writing and editing. All authors read and approved the final manuscript.

\section{Acknowledgements}

This research was supported by the International Science Program (ISP), Uppsala University, Sweden (Grant No CAM: 02), the International Foundation for Science (IFS), Stockholm, Sweden, and the Organisation for the Prohibition of Chemical Weapons (OPCW), The Hague, The Netherland (Grant No F/ 4238-1). We thank Pr. Karsten Krohn, Department of Chemistry, University of Paderborn, for the NMR spectra analysis.

\section{Author details}

${ }^{1}$ Department of Biochemistry, Laboratory of Microbiology and Antimicrobial Substances, Faculty of Science, University of Dschang, PO Box 67, Dschang, Cameroon. ${ }^{2}$ Department of Chemistry, Laboratory of Natural Product Chemistry, Faculty of Science, University of Dschang, PO Box 67, Dschang, Cameroon. ${ }^{3}$ Department of Biochemistry, Laboratory of Phytobiochemistry and Medicinal Plant Study, Faculty of Science, University of Yaounde I, PO Box 812, Yaounde, Cameroon.

Received: 5 April 2012 Accepted: 30 June 2012

Published: 18 July 2012

\section{References}

1. Zabala NQ: Albizia and Paraserianthes species. Suriqao; del Sur, Philippines: Proceedings of an international workshop held in Bislig; 1997:13-19.

2. Watt JM, Breyer-Brandwyk MG: The medicinal and poisonous plants of Southern and Easthern Africa. 2nd edition. London: Livingstone; 1962.

3. Van-Wyk BE, Gerick N: People's plants: a guide to useful plants of Southern Africa. Pretoria: Briza publications; 2000. 
4. Haddad M, Miyamoto T, Laurens V, Lacaille-Dubois MA: Two new biologically active triterpenoidal saponins acylated with salicylic acid from Albizia adianthifolia. J Nat Prod 2003, 66:372-377.

5. Candy HA, Brookes KB, Bull JR, MC Garry EJ, Mc Garry JM: Flavonoids of Albizia adianthifolia. Phytochemistry 1978, 17:1681-1682.

6. Eldeen IMS, Elgarashi EE, Van-Staden J: Antibacterial, anti-inflammatory, anti-cholinesterase and mutagenic effects of extracts obtained from some trees used in South African traditional medicine. J Ethnopharmacol 2005, 102:457-464

7. Kishore N, Chansouria JPN, Dubey NK: Antidermatophytic action of the essential oil of Chenopodium ambrosioides and an ointment prepared from it. Phytother Res 1996, 10:453-455.

8. Soberon JR, Sgariglia MA, Sampietro DA, Quiroga EN, Vattuone MA: Antibacterial activity of plant extracts from Northwestern Argentina. J Appl Microbiol 2007, 102:1450-1461.

9. Holliinworth $\mathrm{H}$ : The management of infected wounds. Professional Nurse 1997, 12:8-11.

10. Sholichin M, Yamasaki K, Kasai $\mathrm{R}$, Tanaka $\mathrm{O}:{ }^{13} \mathrm{C}$ Nuclear magnetic resonance of lupine-type triterpenes, lupeol, betulin and betulinic acid. Chem Pharm Bull 1980, 28:1006-1008.

11. Banerji A, Ray R: Aurantiamide a new class of modified dipeptides from Piper aurantiacum. Phytochemistry 1981, 20:2217-2220.

12. International Organization for Standardization (ISO) 14502-1: Determination of substances characteristic of green and black tea. Part 1: Content of total polyphenols in tea: Colorimetric method using Folin-Ciocalteu reagent; 2005.

13. Tamokou JD, Tala FM, Wabo KH, Kuiate JR, Tane P: Antimicrobial activities of methanol extract and compounds from stem bark of Vismia rubescens. J Ethnopharmacol 2009, 124:571-575.

14. Nyaa TBL, Tapondjou AL, Barboni L, Tamokou JD, Kuiate JR, Tane P, Park HJ: NMR assignment and Antimicrobial/antioxidant activities of $1 \beta$-hydroxyeuscaphic acid from the seeds of Butyrospermum parkii. Nat Prod Sci 2009, 15:76-82.

15. Rice-Evans C, Miller NJ: Total antioxidant status in plasma and body fluids. Methods Enzymol 1994, 234:279-293.

16. Singleton VL, Orthofer R, Lamuela-Ravento's RM: Analysis of total phenols and other oxidation substrates and antioxidants by means of Folin-Ciocalteu reagent. Method Enzymol 1999, 299:152-178.

17. Carbonnelle B, Denis F, Marmonier A, Pinon G, Vague R: Bactériologie médicale: Techniques usuelles. Paris: SIMEP; 1987.

18. Tene M, Tane P, Tamokou JD, Kuiate JR, Connolly JD: Degraded diterpenoids from the stem bark of Neoboutonia mannii. Phytochemistry Lettters 2008, 1:120-124.

19. Kabara JJ: Toxicological, bacteriological and fungicidal properties of fatty acids and some derivatives. J Am Oil Chem Soc 1979, 56:760A-767A.

20. Nazif NM: Phytoconstituents of Zizyphus spina-christi L. fruits and their antimicrobial activity. Food Chem 2002, 76:77-81.

21. Ragasa CY, Penalosa BA, Rideout JA: A bioactive dipeptide derivative from Malachra fasciata. Philipp J Sci 1998, 127:267-276.

22. Singh B, Singh S: Antimicrobial activity of terpenoids from Trichodesma amplexicaule Roth. Phytother Res 2003, 17:814-816.

23. Jung MJ, Chung HY, Kang SS, Choi JH, Bae KS, Choi JS: Antioxidant activity from the stem bark of Albizia julibrissin. Arch Pharm Res 2003, 26:458-462.

24. Roginsky V, Lissi EA: Review of methods to determine chainbreaking antioxidant activity in food. Food Chem 2005, 92:235-254.

25. Chen H, Ho CT: Comparative Study on Total Polyphenol Content and Total Antioxidant Activity of Tea (Camellia sinensis). In Antioxidant Measurement and Applications; ACS Symposium Series 956. Washington, DC: American Chemical Society; 2007:195-214.

26. Hall CA, Cuppett SL: Structure activities of natural antioxidants. In Antioxidant Methodology in Vitro Concepts. Edited by Hudson BJL. London: Elsevier Applied Science; 1997:1-18.

27. Pietta $P$, Sionetti $P$, Mauri P: Antioxidant activity of selected medicinal plants. J Agric Food Chem 1998, 46:4487-4490

28. Bacq-Calberg CM, Coyotte J, Hoet P, Nguyem-Disteeche M: Microbiology Bruxelle: De Boeck and Larcier; 1999

29. Savafi L, Duran N, Savafi N, Onlem Y, Ocak S: The prevalence and resistance patterns of Pseudomanas aeruginosa in intensive care units in a university Hospital. Turk J Med Sci 2005, 35:317-322.
30. Tamokou JD, Kuiate JR, Tene M, Nwemeguela KTJ, Tane P: The Antimicrobial activities of extract and compounds isolated from Brillantaisia lamium. Iran J Med Sci 2011, 36:24-31.

31. Mohammad AH, Shigefumi M, Kotaro M, Hiroshi K, Eisuke S, Kazunori T, Takayoshi T, Shigera K: In vitro and in vivo activities of SCH56592 against Cryptococcus neoformans. J Antimicrob Chemother 1999, 44:827-829.

doi:10.1186/1472-6882-12-99

Cite this article as: Tamokou et al:: Antioxidant and antimicrobial activities of ethyl acetate extract, fractions and compounds from stem bark of Albizia adianthifolia (Mimosoideae). BMC Complementary and Alternative Medicine 2012 12:99.

\section{Submit your next manuscript to BioMed Central and take full advantage of:}

- Convenient online submission

- Thorough peer review

- No space constraints or color figure charges

- Immediate publication on acceptance

- Inclusion in PubMed, CAS, Scopus and Google Scholar

- Research which is freely available for redistribution

Submit your manuscript at www.biomedcentral.com/submit
C) Biomed Central 